Jurnal Ilmu Olahraga Volume I Nomor 1 Oktober 2018

Suleman

Tersedia di http://jurnal.untan.ac.id/index.php/jilo

\title{
PENINGKATAN KEBUGARAN JASMANI MELALUI JUMPROPE EXERCISE YANG DIUKUR DENGAN ROCKPORT PADA SISWA KELAS X MIA 4 SMA NEGERI 10 YOGYAKARTA
}

\author{
Suleman \\ Guru SMA N 10 Yogyakarta \\ Email: sulaeman@gmail.com
}

\begin{abstract}
Abstrak
Rendahnya kebugaran jasmani siswa bisa terjadi karena kurangnya aktifitas peserta didik yang tidak terprogram dan terukur, anak hanya menginginkan bentuk permainan yang menurutnya menyenangkan. Demikian pula dengan rendahnya kebugaran siswa pada materi pembelajaran pendidikan jasmani. Dalam upaya untuk mengatasi permasalahan tersebut dilakukan penelitian dengan intervensi latihan mengunakan tali. Penelitian ini merupakan penelitian tindakan kelas (PTK) yang terdiri dari dua siklus. Subjek penelitian adalah siswa kelas X MIA4 SMA Negeri 10 Yogyakarta berjumlah 29 siswa. Penelitian dilakukan dengan melalukan lopat tali/jump-rope sebelum melakukan kegiatan pembelajaran pendidikan jasmani dilakukan. Instrumen yang digunakan dalam penelitian ini adalah dengan lari/ jalan sejauh 1,6 $\mathrm{km}$. Hasil penelitian menunjukkan dalam dua siklus kebugaran jasmani mengalami peningkatan .
\end{abstract}

Kata kunci: kebugaran Jasmani, rockport.

\section{JUMPROPE EXERCISE FOR HIGHER STUDENT'S FITNESS IN X GRADE SMA N 10 YOGYAKARTA}

\begin{abstract}
Less level student fitness couse inactivity and unwell program physical education, in Physical education students just want to play to have fun. Others unquality of physical education programs. To solve the problems used jumprope training with classrom action research with samples 29 students grade X of SMA N 10 Yogyakarta.. Instrument for measurement of fitness by $1.6 \mathrm{~km}$ walk and run test Student did jumprope activity before the physical education programs. Research showed in two step research classroom action research student's fitness achievement improve.
\end{abstract}

Key words: fitness, rockport. 
Jurnal Ilmu Olahraga Volume I Nomor 1 Oktober 2018

Suleman

Tersedia di http://jurnal.untan.ac.id/index.php/jilo

\section{PENDAHULUAN}

Pendidikan jasmani dan kesehatan itu sangat penting untuk kesehatan siswa siswa kita, dengan kenyataan diberlakukannya kurikulum 2013 yang lebih berat, dimana rata rata siswa pulang pukul 15.00 sehingga kesempatan untuk berolahraga itu rendah sehingga siswa siswa kita tidak mempunyai kebugaran yang cukup baik. Melalui pengamatan ini (latar belakang ini) penulis melaksanakan penelitian yang berjudul Peningkatan kebugaran jasmani menggunakan lompat tali yang diukur dengan metode Rockport pada siswa kelas X MIA4 SMA Negeri 10 Yogyakarta. Salah satu penyebab kurang berhasilnya suatu pembelajaran adalah rendahnya motivasi siswa dalam mengikuti pembelajaran termasuk didalamnya untuk mencapai kebugaran jasmani secara pribadi.

Berdasarkan data hasil kebugaran jasmani pada dua tahun terakhir keberhasilannya rendah. Tahun Pelajaran (Tapel) 2012/2013 persentase hasil kebugan $60 \%$. Tapel 2013/2014 persentase hasil kebugaran $75 \%$. Setelah melakukan pengamatan, hal ini disebabkan oleh pembelajaran yang memanjakan siswa dimana siswa tidak mau melakukan dengan sungguh sungguh kegiatan yang dirasa memberatkan dalam kegiatannya.

Terkait dengan hal tersebut di atas, maka dibutuhkan cara untuk meningkatkan hasil pembelajaran untuk mencapai kebugaran jasmani. Dengan demikian melalui metode rockport siswa diharapkan akan didapat solusi atau jawaban tentang cara mencapai kebugaran jasmani kepada siswa SMA, khususnya siswa SMAN 10 Yogyakarta. Permasalahan diatas adalah sekelumit penyebab mengapa kebugaran jasmani dalam mata pelajaran pendidikan jasmani masih rendah. Dalam upaya meningkatkan kebugaran jasmani tersebut perlu adanya langkah kongkrit dari guru penjas, yang salah satunya yaitu dengan lompat tali yang diukur dengan metode rockport yang akan dibahas pada penelitian ini. Dengan adanya penelitian ini diharapkan dapat menemukan solusi atas rendahnya kebugaran jasmani para siswa.

Metode rockport yang akan diangkat dalam penelitian ini melibatkan pihak lain sebagai kolaborator dan dilaksanakan dengan biaya seminim mungkin tetapi dapat mencapai hasil semaksimal mungkin, sehingga manfaatnya dapat dirasakan langsung baik oleh siswa, guru maupun pihak sekolah. Upaya yang dapat dilakukan guna mencari solusi yang terbaik untuk memecahkan permasalahan tersebut antara lain menggunakan metode pembelajaran rockport. Setelah itu dilanjutkan dengan memptaktekkan metode rockport. Diakhiri dengan melakukan evaluasi terhadap kegiatan yang telah berhasil dilakaukan. Dalam hal ini penyebab rendahnya kebugaran jasmani dapat diidentifikasi sebagai berikut kebugaran siswa yang masih rendah, siswa belum memiliki kesadaran akan pentingnya manfaat kebugaran jasmani, dan kesempatan siswa untuk meningkatkan kebugaran jasmani belum dapat tercapai secara maksimal.

\section{METODE}

Penelitian ini merupakan penelitian tindakan kelas (PTK) atau Classroom Action Research yang berfokus pada upaya untuk mengubah kondisi nyata yang ada sekarang ke arah yang diharapkan. Kemmis dan Mc Taggart (1988: 5) menyebutkan bahwa : penelitian tindakan kelas merupakan salah satu bentuk penelitian refleksi diri (self reflectiv) yang dilakukan oleh guru dalam situasi sosial untuk meningkatkan kemampuan berfikir dalam proses maupun praktek pendidikan juga pemahaman 
Jurnal Ilmu Olahraga Volume I Nomor 1 Oktober 2018

Suleman

Tersedia di http://jurnal.untan.ac.id/index.php/jilo

terhadap praktek serta situasi tempat praktek dilaksanakan.

Sedangkan menurut John Elliott (2008) : Penelitian tindakan adalah proses mengkombinasikan praktek dan mengevaluasi secara bersamaan. Meningkatkan kesadaran atas teori personal, artikulasi sebuah pembagian nilai-nilai, mencoba strategi-strategi untuk memberikan nilai-nilai yang dieskpresikan pada praktik-praktik yang lebih konsisten. Dengan nilai-nilai pendidikan yang mendukung, merekam /mencatat pekerjaan dalam sebuah bentuk yang disediakan, agar dimengerti oleh guruguru lain, dan kemudian membangun teori yang baru

Dengan demikian penelitian tindakan kelas dalam penelitian ini adalah bentuk penelitian yang dilakukan oleh guru secara kolaborasi dalam proses pembelajaran guna memperbaiki keadaan agar menjadi lebih baik. Oleh karena itu guru perlu melakukan tindakan untuk memecahkan masalah yang dihadapinya agar proses pembelajaran berlangsung lancar, sehingga tujuan pembelajaran dapat dicapai secara efisien. Melalui pendekatan penelitian tindakan kelas ini permasalahan-permasalahan yang dirasakan dan ditemukan oleh guru dan siswa dapat dicarikan solusinya.

Prosedur penelitian Penelitian Tindakan Kelas yang dikembangkan dalam penelitian ini adalah prosedur yang dikemukakan oleh (Kemmis \& Taggart 1988:11-14) yang menggambarkan bahwa penelitian tindakan dilaksanakan melalui beberapa siklus, dan tiap-tiap siklus terdiri dari 4 tahap. Adapun

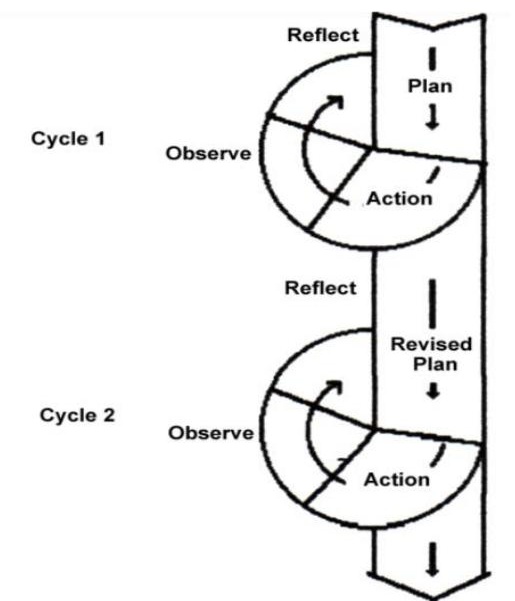

tahap-tahap tersebut adalah sebagai berikut:

\section{Perencanaan (planning)}

Pada tahap perencanaan ini kegiatan yang dilakukan adalah menentukan fokus penelitian. Selanjutnya guru merencanakan dan mengevaluasi pelaksanaan pembelajaran yang telah berlangsung sebelumnya, mendata kelemahankelemahannya, diidentifikasi dan dianalisis kelayakannya untuk diatasi dengan penelitian tindakan kelas.

Dalam tahap perencanaan, peneliti bersama kolaborator merencanakan skenario pembelajaran dan juga menyiapkan fasilitas pendukung untuk melaksanakan skenario tindakan tersebut. Secara rinci kegiatan yang dilakukan dalam tahap perencanaan adalah: Tujuan penelitian dan rencana tindakan disosialisasikan kepada kolaborator dan siswa. Peneliti, kolaborator dan siswa melakukan tukar pikiran untuk menyamakan persepsi. Menyiapkan fasilitas pembelajaran, peneliti membuat dan menyusun instrumen untuk melakukan monitoring pelaksanaan pembelajaran Menentukan teknis pelaksanaan penelitian. Menyiapkan kegiatan refleksi.

Pelaksanaan (action)

Dalam tahap ini untuk mengatasi masalah-masalah yang telah terpilih, peneliti melaksanakan pembelajaran dengan menggunakan strategi-strategi yang sesuai, 
dalam hal ini adalah melalui lompat tali untuk meningkatkkan daya tahan tubuh peserta didik sehingga lebih menjadi baik. Pengamatan (observation)

Kolaborator mengamati, mencatat dan kemudian mendokumentasikan hal-hal yang terjadi selama tindakan berlangsung, dengan maksud untuk mengetahui kesesuaian antara pelaksanaan tindakan dengan rencana tindakan yang telah ditetapkan. Pengamatan yang dilakukan kolabolator memanfaatkan lembar observasi guru , lembar observasi siswa, cacatan lapangan dan kamera digital.

Umpan Balik (feed back)

Dalam tahap refleksi peneliti bersama kolaborator mendiskusikan hasil pengamatan yang telah dilakukan. Kelemahan dan kekurangan yang telah ditemukan pada siklus terdahulu dapat digunakan sebagai dasar penyusunan rencana tindakan pada siklus berikutnya, sehingga siklus selanjutnya akan menjadi lebih baik dari pada siklus sebelumnya.

Langkah-langkah penelitian tindakan secara keseluruhan berbentuk spiral. Setiap lingkaran pada spiral tersebut mengambarkan kegiatan yang utuh, yang dinamakan siklus, karena kalau hanya terdiri dari satu siklus belum berbentuk spiral. Maksudnya agar kekurangan pada siklus pertama dapat diperbaiki pada siklus-siklus berikutnya, sehingga terjadi peningkatan hasil belajar secara terus menerus. Adapun pengertian siklus disini adalah suatu putaran kegiatan yang terdiri dari perencanaan, tindakan, observasi dan refleksi. Siklus akan terus berulang sampai tercapai ukuran keberhasilan yang diinginkan.

Menurut Jahar

$(2010,33)$

pembelajaran kooperatif memang mengurangi peran dominan guru dalam pembelajaran.

\section{HASIL}

Untuk mendapatkan validasi data dalam penelitian ini kita menggunakan trianggulasi peneliti yaitu kita memadukan atau menggabungkan pendapat dari kolaborator peneliti dan peserta didik yang terlibat dalam penelitian ini.

\section{Siklus Pertama}

Perencanaan.

Langkah pertama siswa menerima penjelasan mengenai batasan gerakan pemanasan, gerakan inti dan gerakan penenangan / colling down, setelah itu siswa diberikan kesempatan untuk jalan lari dengan jarak 1,6 km secara kelompok untuk mengetahui seberapa jauh kebugaran yang dimilikinya, guru sebagai fasilitator akan mencatat data yang ada sebagai bahan untuk melakukan tindakan selanjutnya.

Pelaksanaan.

Setelah memberikan penjelasan terlebih dahulu kepada siswa mengenai cara meningkatkan kebugaran jasmani , kemudian memberikan kesempatan kepada siswa untuk melaksanakan kegiatan lompat tali selama 3 - 5 menit. Setelah itu guru sebagai fasilitator menampung / mengakomodir dan memberi kesempatan untuk mengkoreksi benar dan tidaknya lompat tali yang dilakukan.

Pengamatan.

Setelah melaksanakan tindakan pada siklus pertama, satu demi satu siswa diminta memberikan komentar tentang pembelajaran yang baru saja dilakukannya dengan menjawab pertanyaan melalui angket, dengan 29 orang siswa, hasilnya : 21 siswa atau 65,63 \% dari jumlah siswa merasa senang dengan alasan :lebih merasa senang karena jarak yang ditempuh tidak terlalu jauh, tidak jenuh dalam mengikuti pembelajaran, suasana belajar lebih serius, dan merupakan media (alat ukur) untuk 
menunjukkan kebugaran dan pendapat lain yang senada.

Sedangkan 8 siswa atau 34,37\% dari jumlah siswa merasa tidak senang dengan alasan merasa berat untuk mencapai kebugaran, menemui kesulitan dalam mencapai kebugaran, memakan banyak tenaga dalam mencapai kebugarannya.

\section{Refleksi}

Dari hasil pengamatan yang dilakukan pada siklus pertama sebagian besar siswa sudah merasa senang dan menyatakan setuju, namun masih ada beberapa siswa yang merasa tidak senang dan tidak setuju dengan alasan merasa berat untuk mencapai kebugaran, menemui kesulitan dalam mencapai kebugaran, dan memakan banyak tenaga dalam mencapai kebugarannya

Untuk mencari pemecahan masalah tersebut perlu merencanakan suatu solusi yang akan diterapkan pada siklus kedua yaitu dengan menggunakan metode lompat tali/ skiping.

\section{Siklus Kedua.}

Perencanaan

Pada perencanaan siklus kedua ini siswa akan ditugaskan membentuk kelompok dengan jumlah anggota satu kelompok 4 sampai 6 orang siswa. Diharapkan dengan pengelompokkan tersebut siswa akan lebih mudah mencari gerakan yang tepat dan dapat mencapai kebugaran yang diinginkan dan melakukan sharing dengan teman satu kelompok.

Pelaksanaan.

Pada pertemuan kedua ini dalam kegiatan inti siswa dibagi menjadi empat kelompok yang satu kelompoknya beranggotakan 4 sampai 6 orang siswa. Bersama kelompoknya masing masing siswa bertukar pikiran / tukar ide dan melakukan sharing tentang gerak lompat tali/sliping yang benar cara melakukannya. Pada pelaksanaan pembelajaran ini siswa cukup bersemangat dalam melaksanakan geraknya.

Pengamatan.

Setelah melakukan pembelajaran pada siklus kedua siswa diminta memberikan komentar/ pendapat tentang pembelajaran yang baru saja dialaminya dengan menjawab pertanyaan melalui angket, hasilnya 22 orang siswa atau 75,86\% dari seluruh siswa merasa senang dengan alasan Lebih merasa senang karena jarak yang ditempuh tidak terlalu jauh, Tidak jenuh dalam mengikuti pembelajaran, suasana belajar lebih serius, dan merupakan media (alat ukur) untuk menunjukkan kebugaran dan pendapat lain yang senada.

Sedangkan 7 siswa atau 24,14\% dari seluruh siswa merasa kurang senang dengan alasan merasa berat untuk mencapai kebugaran, menemui kesulitan dalam mencapai kebugaran. , dan Memakan banyak tenaga dalam mencapai kebugarannya.

\section{Refleksi}

Dari hasil pengamatan yang dilakukan pada siklus kedua sebagian besar siswa merasa senang dan menyatakan setuju, namun masih ada beberapa siswa yang merasa tidak senang dan tidak setuju dengan alasan merasa berat untuk mencapai kebugaran, menemui kesulitan dalam mencapai kebugaran, dan memakan banyak tenaga dalam mencapai kebugarannya.

Dari hasil pengamatan yang dilakukan pada siklus kedua sebagian besar siswa sudah merasa senang dan menyatakan setuju, dan hanya beberapa siswa saja yang merasa tidak senang dan tidak setuju, ini menandakan penelitian yang baru saja dilakukan menunjukkan korelasi positif bahwa pembelajaran lompat tali dapat meningkatkan kebugaran jasmani. 
Jurnal Ilmu Olahraga Volume I Nomor 1 Oktober 2018

Suleman

Tersedia di http://jurnal.untan.ac.id/index.php/jilo

KESIMPULAN DAN SARAN

Kesimpulan

Melalui menelitian yang dilakukan dalam dua siklus, dan dari hasil pembahasan penelitian ini dapat disimpulkan bahwa :

Penerapan metode lompat tali/ skiping dapat meningkatkan kebugaran jasmani. Siswa lebih banyak memiliki kesempatan untuk mencapai kebugaran jasmaninya.

\section{Saran.}

Penelitian ini dapat digunakan sebagai salah satu langkah alternatif untuk Meningkatkan kebugaran jasmani siswa di SMA Negeri 10 Yogyakarta khususnya dan sekolah lain pada umumnya. perlu adanya sosialisasi penerapan metode lompat tali/skiping dalam mencapai kebugaran jasmani sebagai referensi.

\section{DAFTAR PUSTAKA}

Sardiman A, 1990. Interaksi dan Motivasi Belajar Mengajar. CV. Rajawali Pers.

Jakarta.

Tabrani Rusyan, dkk,1989. Pendekatan dalam Proses Belajar Mengajar. CV.

Remaja Rosdakarya. Bandung.

Heinz Kcok, 1991.Saya Guru Yang Baik, Kanisius. Yogyakarta.

Suryadi Suryabrata, 1984. Psikologi Pendidikan, Rajawali Press Jakarta

Kemmis, Stephen \& Mc. Taggart, Robin.(1988). The action research planner. Victoria: Deakin University.

Departemen Pendidikan Nasional. (2006). Silabus mata pelajaran pendidikan jasmani olahraga dan kesehatan.Jakarta: Direktorat Pembinaan Sekolah Menengah Atas.

Wayan Ardhana, 1985. Pokok-pokok Jiwa Umum. Usaha Nasional.Surabaya

Drs. Roji, 1994. Buku pegangan guru ; Intan Pariwara.
Winskel, W. S. 1987. Psikologi Pengajaran. Jakarta ; Gramedia. 